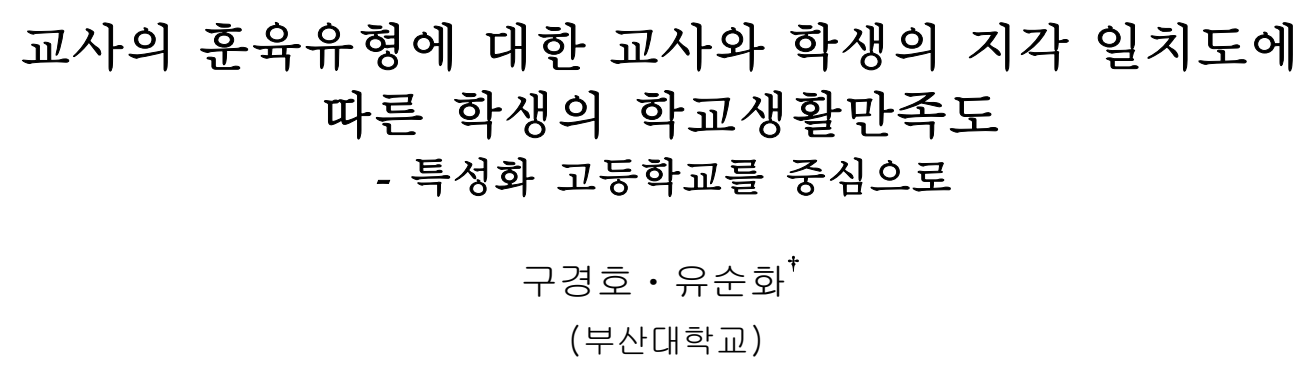

\title{
An Analysis of School Life Satisfaction According to the Consensus of Class Teacher's Discipline Style Perceived by between Teacher and Student
}

- Focused on Special high school Kyung-Ho $\mathrm{KOO} \cdot$ Soon-Hwa $\mathrm{YOO}^{+}$

(Pusan National University)

\begin{abstract}
The purpose of this study was to help teachers increase the level of student's school life satisfaction by comparing between the practical data of a group which have an accordant perception for class teacher's discipline style perceived by between teacher him/herself and student with another group which have a discordant perception for class teacher's discipline style perceived by between teacher him/herself and student.

For this study, 1460 second grade special high school students in Pusan were selected. And 1273 students and 56 teachers' questionnaires were used for analysis, while 5 questionnaires went uncompleted. T-test and Multiple Regression Analysis were used for compiling statistics of collected data.

The results of this study are as follows: First, perceptions about the teacher's discipline style perceived by between teacher him/herself and student were different. Second, the levels of student's school life satisfactions were different by two group. A group which has an accordant perception for class teacher's discipline style perceived by teacher him/herself and student shows the high level of school life satisfaction than B group which has an discordant perception. Last, class teacher's discipline style which affects the level of student's school life satisfaction was different by the two group.

These results suggest that to increase the level of student's school life satisfaction, class teachers have to a mutual understanding first, and then approach their students with different discipline style by the level of their interactive relationship with their students.
\end{abstract}

Key words : Class teacher's discipline style, Level of school life satisfaction

\footnotetext{
† Corresponding author: 051-510-2605, shyouu@pusan.ac.kr
} 


\section{I. 서 론}

학생에게 학교는 성인기로의 발달단계 중에 속 하게 되는 매우 중요한 사회 형태이며 제 2의 가 정이라 할 만큼 영향력이 크다. 학교는 교육목적 을 달성하기 위해 교육활동이 이루어지는 곳이며 학생들은 학교에서 교과활동, 특별활동, 학생자치 회, 정기적 학교행사 등 교사와 동료학생들과의 상호작용을 하게 되는데 이런 일련의 활동을 통 틀어 학교생활이라 할 수 있다. 특별히 입시위주 에 집중된 생활을 하는 우리나라 청소년들은 학 교라는 공간에서 대부분의 시간을 보내기에 학교 는 청소년의 다른 활동 공간인 가정, 사회 보다 많은 영향을 받는 장소이며 또한 생활 공간이다.

학교생활의 구성요소는 학생과 교사와의 관계, 학생상호간의 관계, 학교생활 등이다. 학생들은 많은 시간을 학교에서 보내면서 학교생활 구성요 소와의 상호작용을 통해 학교생활 만족감을 형성 하며 이런 결과는 학생들의 정서와 행동에 영향 을 미치게 된다. 계선자(2001)는 학교생활만족 정 도는 청소년들의 삶의 질에 많은 영향을 주는 요 소라고 한다.

학교생활만족도란 학생들이 인간관계, 교과활 동, 행사활동, 특별활동 등의 학교생활 전반에 대 해 주관적, 심리적으로 갖게 되는 긍정적 혹은 부정적인 느낌이나 태도의 정도를 의미한다(이시 연, 2007). 최경소(2003)는 학교생활전반에 대하여 개인이 추구하는 목적이나 욕구가 성취되었을 때 얻어지는 주관적인 감정이라고 정의하였다. 한주 희(2000)는 학교라는 환경적 공간에서 학생들이 교사, 또래 집단과 인간관계를 맺으며 교육활동 을 하는데 충분한가의 정도를 타나낸 것이라고 한다. 대부분의 연구자들은 학교생활만족도는 학 교생활 전반의 행복과 만족에 대한 주관적, 개인 적 감정이라고 강조한다.

학교생활에서 자신의 욕구를 만족시키지 못했 을 때 학생은 자신의 인간관계나 교과활동, 학교
환경과 학교규칙, 학급분위기 적용 등에서 심리 적 긴장감이 발생되고 이는 마음의 균형상실로 나타나게 된다(김대성, 2005). 하지만 학교가 학 생 스스로의 욕구를 충족시킬 수 있는 즐거운 생 활공동체로 발전한다면 학교활동 전반에 대한 학 생들의 감정과 느낌을 보다 긍정적이고 만족스러 운 모습으로 변화시켜 청소년들의 삶의 질이 향 상될 수 있을 것이다(장신국, 2002).

2011년 서울시 교육청이 발표한 '서울형 학생 행복지수'는 100점 만점에 62.5점으로 나타났다. 서울형 학생행복지수는 학교생활만족도, 가정생 활만족도, 자기만족도, 전반적 행복도의 하위 영 역으로 구성되어 있는데, 학교생활만족도와 자기 만족도가 가장 낮게 나타났다. 이는 대학 입시라 는 이유로 학교생활의 대부분이 대학입시를 준비 하는데 집중되어 있어 학생들에게 입시에 대한 중압감과 부담감을 주며 이 시기에 필요한 발달 과업을 채워주지 못하기 때문이다(이미화, 류진 혜, 2002).

특성화 고등학교에서도 대학진학을 위한 입시 부담은 일반계와 비교하여 차이는 있지만 여전히 존재한다. 여기에 일반계 고교 정원에 들어갈 수 없는 성적을 가진 학생들이 특성화고 고교에 진 학한다는 보편적인 사회 인식이 존재해 특성화고 고교에 진학한 학생들을 열등감에 빠지게 하여 특성화고 학생들의 학교생활적응을 방해하고 있 다(이현주, 2002). 실제 특성화고 학생들은 인문 계 학생들보다 학생 수가 적음에도 학교에 부적 응하는 학생들의 비율이 현저히 높다고 한다(김 현임, 2002). 교육통계서비스에 의하면 우리나라 인문계 고등학생은 2012년 현재 1,381,130명이며 이중 부적응 학생수는 7,809 명으로 전체의 $0.6 \%$ 에 해당한다. 반면, 특성화고 학생수는 330,797명 이며 이중 부적응 학생수는 8,094 명으로 전체의 $2.5 \%$ 에 해당하여 특성화 고등학교 학생들이 일반 계 고등학교 학생들보다 약 4 배 정도 학업을 중 단하는 학생들이 많음을 알 수 있다. 과거에는 특성화 고등학교를 포함한 직업교육기관은 국가 
및 산업발전에 필요한 산업인력을 공급하면서 중 요한 공헌을 하였고 그에 상응하는 평가를 받았 다. 하지만 우리사회의 인문숭상의 전통, 기술인 에 대한 천시 풍조 및 인문교육 중심의 교육제도 운영 등으로 인해 고등학교 단계에서의 직업 교 육이 적절한 평가를 받지 못하고 있다. 이와 같 은 상황에서 특성화 고등학교를 활성화하고 더 나아가 국가산업을 발전시키기 위해서는 현재 특 성화고 학생들에게 학교에 대한 긍지와 신뢰를 갖게 하여 학교생활에 대한 만족도를 높여주는 작업이 그 무엇보다 필요하다 하겠다(김숙희, 2003).

학교생활의 구성요소중 학생과 교사와의 관계 는 실질적으로 학생의 교육과 인격형성에 중요한 역할을 담당한다. 학교 생활은 교사와 학생간의 인격적 만남의 장을 통해 이루어지며, 담임교사 는 학생들이 학교생활을 하는데 있어서 교육의 기획자, 학습연구자, 평가자, 지식의 제공자, 훈육 지도자로서의 다양한 역학을 수행하게 된다. 박 관성(1998)은 학교의 조직을 이루는 모든 요인들 중에서 교사가 학생과 가장 가까운 거리에 존재 하며 모든 학생들의 활동에 직접적인 영향력을 행사한다고 하였다. 김현숙(2007)의하면 교사의 훈육은 안정되고 질서 있는 면학 분위기를 조성 하여 학생들의 학업성취를 도와주고, 학생 상호 간의 원만한 관계 조성을 통하여 정서 안정 및 사회성 발달을 촉진하며 학생 개개인의 인성, 자 아개념 및 태도와 행동의 변화를 유도함으로써 학생들의 학교생활 만족도에 영향을 준다고 한 다.

학생의 훈육문제와 질서유지는 학교를 특징짓 는 보편적 현상이며, 학교의 질을 결정하는 중요 한 요소이다. 그것은 학습활동, 학습풍토, 그리고 학습결과에 영향을 주어 학교교육의 질을 결정한 다(박병량, 2001). 김묘정(2008)은 교사가 학급경 영에서 주도적인 역할을 하면서, 학생의 행동에 대하여 큰 영향을 미치고 있으며, 교사의 훈육태 도는 학생들의 인격형성, 자아개념, 사회성 발달
등 정의적 영역의 행동발달과 밀접한 관계를 가 진다고 하였다. 학생훈육은 교사에 의해 영향을 받으며 그만큼 교사에 의한 변화 가능성도 크다. 또한 교사의 훈육방식은 학급질서 유지뿐만 아니 라 학생의 학업성취, 사회성 및 도덕성 발달에 크게 영향을 미친다.

교사의 훈육유형은 학자들에 따라 다양하게 구 분되는데 김달효(2006)는 교사의 훈육유형을 교 사가 학생에게 보여주는 강요와 지원의 정도에 근거하여 민주형, 전제형, 지원형, 방임형, 타협형 으로 구분하여 교사의 훈육유형이 민주형일 때 가장 효과가 있고 방임형일 때 가장 효과가 없다 고 하였다. 김현숙(2007)은 교사의 훈육유형 중 교섭형, 지원형, 타협형이 학생들의 생활만족도를 높이는 요인으로 나타났다 하였다. 황영덕(2008) 은 농업계 고등학교 교사의 훈육유형과 학교부적 응 행동수준의 관계 연구를 통해 담임교사의 훈 육유형에 따라 학생의 학교부적응 행동수준에 차 이가 있는 것을 보고하였다. 즉 학생의 훈육을 다루는 교사의 훈육유형이 학생들에게 주요한 영 향력을 행사하며, 학생의 학교생활 만족에도 영 향을 줄 수 있다는 가능성을 시사한다(박선호, 2007).

교육은 가르치는 사람과 배우는 사람의 상호작 용을 통해 교육적으로 가치를 추구하는 활동임으 로 교육적 상황에서의 교사와 학생의 관계는 매 우 중요한 의미를 지닌다(백순근, 2000). 곽혜영 은(2009) 교사와 아동과의 관계 연구를 통해 교 사와의 관계가 원만한 학생일수록 학교생활에 더 적응을 잘한다고 하였으며, 김현숙(2007)은 교사 의 의사소통 유형과 훈육유형이 학생에게 더 잘 수용될수록 학교생활 만족도가 높다고 한다. 즉, 교사의 훈육유형과 학생과의 상호작용이 학생의 학교생활전반에 긍정적 영향을 미치며 학교생활 만족으로도 이어져 교육의 효과가 커질 수 있다 는 것이다. Furrer \& Skinner(2003)의 연구에서는 교실환경에서 교사와 학생의 의사소통 및 인지의 상호작용이 학생들에게 인지적, 정의적 성취에 
영향을 미친다고 한다. 따라서 교사가 지각한 훈 육유형와 이에 대한 담임학생의 교사의 훈육유형 에 대한 인식의 상호작용이 일치되는 경우 학생 들의 학교생활만족도가 향상되리라 사료된다.

현재까지 학생의 훈육에 관한 연구가 중·고등 학생을 대상으로 이루어지고 있으며, 아직까지 초등학생이나 유아를 중심의 연구에 비해 많이 이루어지지 않은 실정이다. 고교생이 지각한 담 임교사의 훈육유형이 학교생활만족도에 미치는 영향에 대한 연구가 일어나고 있으나, 교사가 지 각한 훈육유형과 담임학생이 지각한 훈육유형의 일치여부와 상호간 인식일치를 이루는 학생 그룹 의 학교생활만족도와 그렇지 못한 학생 그룹의 학교생활만족도에 관한 비교 연구는 부족한 상태 이다. 특별히 직업적성보다 성적으로 인해 특성 화고에 입학한 고등학생의 경우 학교부적응의 경 우가 많이 보고됨으로 이들이 학교에 잘 적응하 여 학교생활 만족을 높일 수 있는 연구도 필요하 다.

이에 본 연구에서는 특성화고 고등학생을 중심 으로 교사가 지각한 훈육유형과 담임학생이 지각 한 훈육유형의 결과 비교와 교사-학생간 훈육방 식 지각이 일치하는 학생 그룹과 일치하지 않는 학생 그룹의 학교생활만족도를 비교 분석하여 교 사-학생간의 인식의 상호작용과 이에 맞춘 훈육 방식이 그렿지 않은 경우보다 학교생활만족도에 미치는 영향이 다름을 알아보며, 이에 따른 담임 교사의 바람직한 훈육방식을 제시하고자 한다. 이상에 따른 연구문제는 다음과 같다.

첫째, 교사가 지각한 훈육유형과 담임학생이 지각한 훈육유형은 차이가 있는가?

둘째, 교사-학생간 훈육유형 지각이 일치하는 학생 그룹과 일치하지 않는 학생 그룹의 학교생 활만족도는 어떠한 차이가 있는가?

\section{II. 연구 방법}

\section{1. 연구대상}

본 연구는 부산광역시에 위치한 특성화고 고등 학생을 대상으로 하였다. 학생용 설문지는 총 1460 명을 대상으로 하여 배부하였으며 1278 부를 회수하였다. 회수된 설문지 중에서 응답률이 저 조하거나 대부분의 문항에 대해 같은 번호로 응 답한 설문지를 제외한 1273 부를 통계처리 하였 다. 담임 선생님용 설문은 10 명 이상 응답한 고 교 학급 담임 56 명을 대상으로 실시하였다.

\section{2. 연구도구}

\section{가. 훈육유형}

학생이 지각한 담임교사의 훈육유형을 측정하 기 위해 김달효(2006)가 초등학생을 대상으로 제 작한 검사를 황영덕(2008)이 고등학생의 발달단 계에 맞는 표현으로 재구성한 설문지를 사용하였 다. 김달효(2006)의 설문지는 총 5 개 영역 47 문항 으로 구성되어 있는데 황영덕(2008)은 이 검사문 항을 민주형(6문항), 지원형(6문항), 타협형(6문 항), 방임형(6문항), 전제형(6문항)의 총 5 개 영역 30 문항으로 수정하였다.

본 연구의 결과에 측정된 내적 합치도 (Cronbach's a)는 .78이며, 5개 요인별 신뢰도는 .70 .84사이에 분포하였다.

나. 학교생활만족도

학생들의 학교생활만족도를 측정하기 위해 김 주연(2008)이 선행연구자들이 분류한 여러 가지 요인들을 기준으로 하위영역을 종합, 정리하여 Likert 5점 척도로 제작한 설문지를 사용하였다. 설문문항은 총 6 개 영역 25문항으로 구성되어 있 으며 하위 변인으로는 학교생활 전반적 만족감(3 문항), 대인관계 만족감(4문항), 수업과 학습활동 만족감(4문항), 교육환경 만족감(4문항), 학교규칙 및 특별활동 만족감(4문항), 교육환경 만족감(4문 항), 학교규칙 및 특별활동 만족감(4문항), 사회적 지지 만족감(6문항)으로 구성되어 있다.

김주연(2008)의 연구에서는 신뢰도가 .74 .80 
사이에 분포하였다. 본 연구의 결과에 측정된 내 적 합치도(Cronbach's a)는 .91이며, 6개의 하위 요인별 신뢰도는 .66 .84사이에 분포하였다.

\section{3. 자료 분석}

교사가 지각한 훈육유형과 담임학생이 지각한 훈육유형을 대표유형별로 분류하고 교사-학생간 훈육유형 지각에 대한 비교를 위해 기술통계를 실시하였다.

교사-학생간 훈육유형 지각이 일치하는 학생 그룹과 일치하지 않는 학생 그룹의 학교생활만 족도 차이 검증을 위해 $\mathrm{t}$-검증을 실시하였다.

\section{III. 연구 결과}

\section{1. 교사가 지각한 훈육유형과 담임학생이 지각한 훈육유형 비교}

본 연구에서 제시한 연구문제를 검증하기 위한 기초자료로서 연구대상인 특성화고 고등학생이 지각한 담임교사 훈육유형과 담임교사가 지각한 훈육유형의 평균 및 표준편차를 표 1 에 제시하였 다.

<표 1>에 나타난 바와 같이 특성화고 고등학 생들이 지각한 담임교사의 훈육유형은 지원형 (20.75)이 가장 높았으며, 다음으로 민주형(19.58), 타협형(17.33), 전제형(16.60)순으로 나타났으며, 담임교사의 훈육유형 중 방임형(12.56)에 대한 지 각은 가장 낮은 것으로 드러났다. 담임교사 훈육 유형 중 지원형과 민주형은 이론적 평균 점수인 18점 이상을 기록함으로써 평균보다(총 30 문항 중 하위 유형별 문항은 총 6 문항으로 모두 5점 척도이며, 6문항 모두를 '보통이다'(3점)로 응답했 을 경우 평균점수는 18 점으로 나타난다) 높으며, 타협형, 방임형, 전제형은 평균보다 낮음을 알 수 있다.

특성화고 교사의 실제 사례 수는 56명이며, 담 임교사가 지각한 훈육유형은 지원형(25.68)이 가
장 높았으며, 다음으로 민주형(24.59), 타협형 (19.30), 전제형(15.68)순으로 나타났으며, 담임교 사의 훈육유형 중 방임형(10.50)에 대한 지각은 가장 낮은 것으로 드러났다.

담임교사 자신이 지각한 훈육유형 중 지원형과 민주형, 타협형은 이론적 평균 점수인 18점 이상 을 기록함으로써 평균보다(총 30 문항 중 하위 유 형별 문항은 총 6 문항으로 모두 5점 척도이며, 6 문항 모두를 '보통이다'(3점)로 응답했을 경우 평 균점수는 18 점으로 나타난다) 높으며, 방임형, 전 제형은 평균보다 낮음을 알 수 있다.

<표 $1>$ 학생과 교사가 지각한 훈육유형의 평균 과 표준편차 $(N=1273)$

\begin{tabular}{|c|c|c|c|c|}
\hline \multirow[t]{2}{*}{ 변인 } & \multicolumn{2}{|c|}{$\begin{array}{c}\text { 특성화 } \\
\text { 고등학생이 } \\
\text { 지각한 교사의 } \\
\text { 훈육유형 } \\
(N=1273)\end{array}$} & \multicolumn{2}{|c|}{$\begin{array}{c}\text { 담임교사가 } \\
\text { 지각한 자신의 } \\
\text { 훈육유형 }(N=56)\end{array}$} \\
\hline & $M$ & $S D$ & $M$ & $S D$ \\
\hline $\begin{array}{c}\text { 훈육유형 } \\
\text { 전체 }\end{array}$ & 86.82 & 11.0 & 95.75 & 6.11 \\
\hline 민주형 & 19.58 & 4.57 & 24.59 & 3.10 \\
\hline 하 지원형 & 20.75 & 4.35 & 25.68 & 2.54 \\
\hline $\begin{array}{l}\text { 위 타협형 } \\
\text { 변 }\end{array}$ & 17.33 & 4.41 & 19.30 & 3.17 \\
\hline 인 방임형 & 12.56 & 3.59 & 10.50 & 2.83 \\
\hline 전제형 & 16.60 & 4.25 & 15.68 & 3.43 \\
\hline
\end{tabular}

<표 1>에 나타난바와 같이 교사가 지각한 본 인의 훈육유형은 학생이 지각한 유형과 달리 지 원형과 민주형에서 매우 높은 평균을 보였으며 (하위변인 총 6문항모두를 '그렇다'(4점)로 응답했 을 경우 평균점수는 24점으로 나타난다), 방임형, 전제형에서는 학생이 지각한 평균점수보다 낮은 것으로 나타났다.

2. 교사-학생간 훈육유형 지각이 일치하는 학생 그룹과 일치하지 않는 학생 그룹분 류 및 비교분석 
교사-학생간 훈육유형이 일치하는 학생 그룹과 일치하지 않는 학생 그룹을 분류하기 위해 먼저 각 학생마다 자신이 지각한 담임교사의 훈육유형 중 평균점수가 가장 높은 유형을 파악하여 대표 유형으로 분류(김달효, 2006; 양은정, 2007)하였으 며, 10 명 이상의 학생들이 설문에 응한 담임교사 56 명이 지각한 자신의 대표 훈육유형도 같은 방 식으로 분류하였고, 그 결과를 살펴보면 <표 2> 와 같다.

<표 2> 특성화고 고등학생 및 담임교사가 지각 한 대표 훈육유형 분류

\begin{tabular}{ccc|ccc}
\hline $\begin{array}{c}\text { 특성화 고등학생이 } \\
\text { 지각한 훈육유형 }\end{array}$ & \multicolumn{3}{|c}{$\begin{array}{c}\text { 담임교사가 지각한 } \\
\text { 본인의 훈육유형 }\end{array}$} \\
\cline { 1 - 4 } 대표 & 빈도 & 백분 & 대표 & 빈도 & 백분 \\
훈육유형 & $($ 명 $)$ & 율 $(\%)$ & 훈육유형 & $($ 명 $)$ & 율 $(\%)$ \\
\hline \hline 민주형 & 242 & 19.0 & 민주형 & 9 & 16.1 \\
지원형 & 518 & 40.7 & 지원형 & 33 & 58.9 \\
타협형 & 74 & 5.8 & 타협형 & 2 & 3.6 \\
방임형 & 33 & 2.6 & 방임형 & 0 & 0 \\
전제형 & 231 & 18.1 & 전제형 & 0 & 0 \\
민주형/지 & 149 & 11.7 & 민주형/지 & 12 & 21.4 \\
원형 & 원형 & & \\
제거 & 26 & 2.0 & 제거 & 0 & 0 \\
전 체 & 1273 & 100 & 전 체 & 56 & 100 \\
\hline
\end{tabular}

<표 2>에 나타난 특성화고 고등학생이 지각한 담임교사의 대표 훈육유형별 분포를 살펴보면 지 원형 $(40.7 \%)$ 이 가장 많고 민주형( $19.0 \%)$, 전제형 $(18.1 \%)$, 민주형과 지원형이 동일점수로 나타난 민주형/지원형(11.7\%), 타협형(5.8\%)의 순으로 나 타났다. <표 2>에 나타난바와 같이 총 사례수 1273 명 중 세 가지 이상의 훈육유형에서 같은 최 고득점을 보인 26명의 사례는 제외하고 중복되지 않은 1247 명의 사례 중 최고득점을 보인 유형을 파악하였다.

<표 2>에 나타난 특성화고 교사가 지각한 자 신의 훈육유형 분포를 살펴보면 사례수 56 명 중 지원형 $(58.9 \%)$ 이 가장 많고, 민주형과 지원형이 동일점수로 나타난 민주형/지원형 $(21.4 \%)$, 타협형
(3.6\%)의 순으로 나타났다. 세 가지 이상의 훈육 유형에서 같은 최고득점을 보인 사례는 없음으로 총 56 명의 사례 중 최고득점을 보인 대표유형을 파악하였다.

<표 2>에 나타난 바와같이 교사가 지각한 본 인의 대표 훈육유형 분류는 학생이 지각한 유형 과 달리 전제형, 방임형이 없으며 지원형이 매우 높은 것으로 나타났다.

\section{<표 3> 교사-학생간 훈육유형 지각의 일치여부 에 따른 그룹 분류}

\begin{tabular}{c|c}
\hline $\begin{array}{c}\text { 교사-학생간 훈육유형 } \\
\text { 지각이 일치하지 않는 } \\
\text { 그릅 }\end{array}$ & $\begin{array}{c}\text { 교사-학생간 훈육유형 } \\
\text { 지각이 일치하는 그룹 }\end{array}$ \\
\hline \hline 590 명 & 657 명 \\
\hline \hline
\end{tabular}

설문 응답자 1273 명 중 세 가지 이상의 훈육유 형에서 최고득점을 보인 26명을 제외한 1247 명이 지각한 대표 훈육유형과 이들의 담임교사 56명이 응답한 훈육유형을 비교하여 그 훈육유형이 일치 하는 학생 그룹과 일치하지 않는 학생 그룹을 분 류하였다.

\section{3. 교사-학생간 훈육유형 지각이 일치하는 학생 그룹과 일치하지 않는 학생 그룹별 학교생활만족도 차이 비교}

본 연구에서 제시한 연구문제를 검증하기 위해 교사-학생간 훈육유형 지각이 일치하는 학생 그 룹과 일치하지 않는 학생 그룹의 평균, 표준편차 및 그룹간 차이 검증을 <표 $4>$ 에 제시하였다.

교사-학생간 훈육유형 지각이 일치하는 학생 그룹과 일치하지 않는 학생 그룹에 따른 학교생 활만족도의 차이 결과는 <표 $4>$ 에 나타난 바와 같다. 훈육유형 지각이 일치하는 학생그룹의 평 균은 88.78 로 일치하지 않는 그룹의 84.65 보다 높 게 나왔으며 통계적으로 $\mathrm{p}<.001$ 수준에서 유의미 한 것으로 드러났다. 학교생활만족도 하위변인에 서도 그룹별 차이가 통계적으로 유의미한 수준에 
서 나타났다.

<표 4> 그룹별 학교생활만족도의 차이 검증

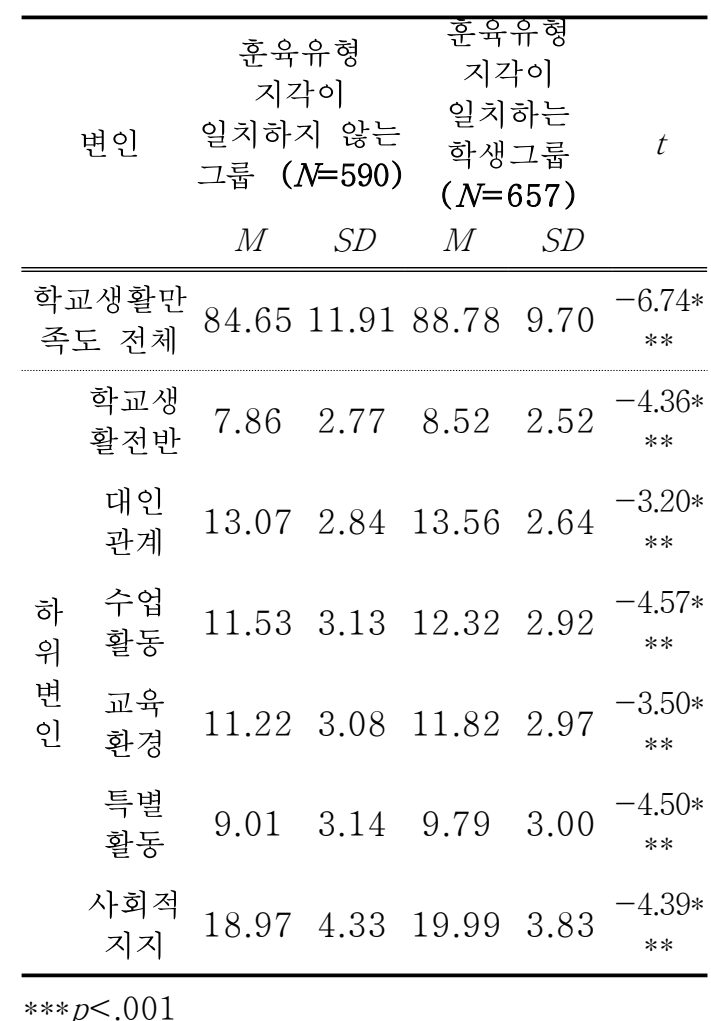

\section{$\mathrm{IV}$. 결 론}

본 연구는 특성화고 학생이 지각한 훈육유형과 담임교사가 지각한 훈육유형의 일치여부와 교사학생간 상호 지각이 일치하는 학생 그룹과 일치 하지 않는 학생 그룹의 학교생활만족도를 차이를 알아보고자 하였다. 본 연구에서 얻은 통계분석 결과를 선행연구 및 연구문제와 관련지어 논의하 면 다음과 같다.

첫째, 특성화고 고등학생이 지각한 담임교사의 훈육유형과 담임교사가 지각한 자신의 훈육유형 에는 차이가 있었다. 교사가 지각한 본인의 훈육 유형은 학생이 지각한 유형과 달리 지원형, 민주 형에서 학생이 지각한 점수보다 높았으며, 방임
형, 전제형에서는 학생이 지각한 평균점수보다 낮게 나타났다. 이는 교사-학생간의 상호 인식차 이에 불일치가 존재한다는 다른 연구결과(김달효, 2006; 오나연, 2010)와 일치하였다. 김달효(2006) 는 교사의 학생훈육 전략과 그 전략에 대한 학생 들의 인지 차이에서 이러한 결과가 비롯될 수 있 으며 또한 교사 자신이 스스로 생각하는 훈육방 식이 실제적으로 그렇지 않다는 것을 깨닫지 못 하여서 발생할 수 있다고 한다. 교사들이 모든 학생들에게 민주적이고 지원적인 훈육의 모습으 로 다가갔다고 할찌라도, 학급운영상 임원학생, 성적이 좋은 학생, 생활태도가 바른 학생 등 교 사의 지시에 쉽게 수긍하는 학생들에게 보여주는 민주형, 지원형의 모습과 통제가 필요하다고 지 각하는 학생들에게 보여준 교사의 민주형적 및 지원형적 접근방식이 달랐기 때문이라 해석된다 (윤준기, 2010).

둘째, 교사가 지각한 대표 훈육유형과 학생이 지각한 대표 훈육유형 중 평균점수가 가장 높은 유형을 담임교사의 대표 훈육유형으로 결정하여 비교하는 대표 훈육유형 분류방식에도 차이가 있 었다. 특성화고 고등학생들이 지각한 담임교사의 대표 훈육유형은 지원형(40.7\%), 민주형(19.0\%), 전제형 $(18.1 \%)$ 이 가장 많은 비중을 차지하였다. 하지만 담임교사 자신이 지각한 대표 훈육유형은 지원형 $(58.9 \%)$ 이 앞도적인 비율을 차지하였다. 이 는 <표1>의 훈육유형의 변인간 평균점수를 비교 하여 본 첫 번째 연구결과와 유사하다. 하지만 훈육유형 중 평균점수가 가장 높은 유형을 응답 자가 지각한 대표유형으로 결정해서 살펴봄으로 그 결과 차는 더 크게 해석되어진 것으로 여겨진 다.

이 결과에서 학생들이 응답한 교사들의 대표 유형 중 전제형은 교사들이 지각한 유형에는 없 다는 점이 주목된다. 이는 우리나라 현실상 특성 화고 고교에 진학한 학생들 대부분이 직업교육과 적성에 따른 진학보다 성적으로 인해 특성화고 고교에 진학을 하며, 이러한 특성으로 특성화고 
고 학생들의 부적응은 일반계 고교 보다 많은편 이다. 따라서, 특성화고 교사들이 학급운영을 위 해 양방향적인 의사소통보다 일방향적인 훈육을 많이 함으로 교사-학생간의 유형인식 차이가 생 겨난 것으로 보인다. 특성화고 고등학생의 학교 생활만족도를 높여주기 위해서 독단적 결정이나 빈번한 통제보다는 설득, 대화, 도움제공, 헌신, 배려 등의 적극적 노력이 필요하다고 여겨진다.

셋째, 교사-학생간 훈육유형 지각이 일치하는 학생 그룹과 일치하지 않는 학생 그룹간의 학교 생활만족도에는 유의미한 차이가 있는 것으로 나 타났다. 교사가 지각한 훈육유형과 학생이 지각 한 교사의 훈육유형이 일치하는 집단은 교사-학 생간 훈육유형 인식이 일치하지 않은 집단보다 학생생활만족 및 6 개의 하위변인(학교생활전반 만족도, 대인관계 만족도, 수업활동 만족도, 교육 환경 만족도, 학교규칙 및 특별활동 만족도, 사회 적지지 만족도) 모두에서 통계적으로 유의미한 수준에서 평균점수가 높았다. 이는 아무리 올바 른 훈육방식으로 교사가 학생에게 접근을 한다 할지라도 학생과의 상호작용과 훈육방식에 대한 이해와 공감이 없다면 그 영향력을 적을 수 밖에 없으며, 그 반대로 학생과 교사의 공감이 클 수 록 학생의 학교 적응에 유의한 차이가 있으며(이 윤정, 2003; 권금진, 2010) 교사-학생의 관계에서 상호신뢰가 학교생활에 영향을 미친다는 연구(설 재연, 2007)과 일부분 일치한다.

본 연구의 결과는 상호작용적인 교사-학생 관 계는 학생들의 태도에도 긍정적인 역할을 하기에 (Pianta \& Steinberg, 1992), 교사는 학생이 어떻 게 인식하고 있는지를 파악하는 것이 중요하다는 것을 주지시켜준다. 이는 학생들의 참여도, 동기 부여, 성취감을 불러일으켜 학교생활만족도를 향 상시킬 수 있는 원동력이 될 수 있기 때문이다.

이상의 결과를 통해 살펴본 본 연구의 시사점 은 다음과 같다.

첫째, 교사-학생간의 훈육방식에 대한 상호 인
식에 불일치가 존재한다. 이는 교사의 학생훈육 전략과 그 전략에 대한 학생들의 인지 차이에서 이러한 결과가 비롯될 수 있으며 또한 교사 자신 이 스스로 생각하는 훈육방식이 실제적으로 그렇 지 않다는 것을 깨닫지 못하여서 발생할 수 있 다. 특성화고 고등학생의 학교생활만족도를 높이 기 위해서는 설득, 대화, 도움제공, 헌신, 배려 및 책임감 부여 등의 양방향적인 대화와 노력을 통 한 교사-학생간의 인식의 상호교감이 먼저 필요 하다.

둘째, 교사-학생간 훈육유형에 대한 인식이 일 치하는 집단은 일치하지 않은 집단에 비해 교사 의 훈육유형이 학생의 학교생활만족도에 더 큰 영향을 미치는 것으로 나타났다. 이는 학생들의 학습동기 향상과 학교생활만족도 향상을 위해 교 사와 학생간의 교감과 상호작용이 밑바탕이 되어 야 하며, 교사와의 협응을 거부하거나, 제대로 되 지 않는 학생들에게는 아무리 올바른 훈육방식으 로 접근하다고 하여도 그 영향력이 제대로 전달 될 수 없다는 근본 원리를 보여준다. 본 연구의 결과는 고등학교 학생의 학교생활만족도 향상을 위해서는 학생들에게 먼저 교사가 상호 이해에 따른 훈육방식을 제시하여야 하며, 전체적이고 집단적인 학생지도 방식보다 개인별 맞춤형적인 이해와 접근이 훈육방식에도 필요함을 시사한다.

본 연구의 제한점과 후속 연구를 위한 제언은 다음과 같다.

첫째, 본 연구는 부산시 소재의 특성화고 학생 을 대상으로 실시되었기 때문에 연구 결과를 모 든 특성화고 고등학생 전체로 일반화하는 데 문 제가 있다. 그러나 통계적 분석의 결과 교사와 학생이 지각한 훈육유형에 따른 학생생활만족도 연구에 유의미한 효과가 있음을 보여주었으므로 계속적인 연구를 통해 그 효과를 확증할 필요가 있다.

둘째, 본 연구에서 사용한 훈육유형은 Tomal (1998)의 교사 훈육유형을 번안하여 사용하였으 므로 우리나라 상황에 맞는 교사의 훈육유형을 
측정하지 못했을 가능성이 있다. 따라서 후속연 구에서는 우리나라 상황을 고려한 훈육유형을 측 정할 수 있는 도구의 개발이 요구된다.

\section{참고 문헌}

강윤정(2006). 아동이 지각한 담임교사의 훈육유 형과 학교생활만족도와의 관계, 한국교원대학 교 대학원 석사학위논문.

강효숙(1990). 아동이 지각한 교사행동과 자아개 념 및 학습태도와의 관계 연구, 숙명여자대학 교 대학원 석사학위논문.

경기도교육청(2005). 경기교육통계연보.

계선자 외(2001). 청소년의 학교생활실태 및 학교 생활만족도, 대학가정학회지 39(2), 57 72.

김달효(2006). 담임교사와 학생의 지각에 따른 초 등담임교사의 훈육유형의 실증적 분류, 한국교 육 33(1), 3-26.

김달효(2006). 담임교사의 훈육유형과 훈육효과 분석, 부산대학교 대학원 박사학위논문.

김대성(2005). 특성화-계고등학교 학생들의 자아 존중감과 학교생활만족도 비교, 연세대학교 교 육대학원 석사학위논문.

김명선(1997). 교사의 훈육유형과 학생들의 자아 개념 및 학습태도와의 관계 연구, 한국교원대 학교 석사학위논문.

김묘정(2008). 담임교사의 훈육유형과 학생의 훈 육문제와의 관계 분석, 부산대학교 대학원 석 사학위논문.

김미경(2000). 고등학교 학생들의 학교생활 만족 도와 그 결정요인에 관한 연구, 아주대학교 교 육대학원 석사학위논문.

김숙희(2003). 실업계고등학교 학생들의 학교생활 만족도 비교연구, 순천대학교 교육대학원 석사 학위논문.

김세환(2005). 계 고등학교 학생들의 학교생활 만 족도에 관한 연구, 관동대학교 교육대학원 석 사학위논문.

김주연(2009). 고등학생의 학교생활만족도 척도개 발 및 타당화 연구, 원광대학교 대학원 박사학 위논문.

김진희(2008). 아동이 지각한 담임교사의 훈육유 형과 훈육효과의 관계, 춘천교육대학교 대학원 석사학위논문.

김해룡(1994). 아동이 지각한 교사 행동과 자아개
념과의 관계, 전남대학교 대학원 석사학위논문 김현숙(2007). 초등학생이 지각한 담임교사 훈육 유형과 학교생활 만족도와의 관계, 춘천교육대 학교 대학원 석사학위논문.

박경란(1988). 노년여성의 생활만족도 연구: 장남 부부와의 관계를 중심으로, 고려대학교 대학원 박사학위논문.

박계원(2003). 초등교사의 행동특성과 아동의 자 아존중감과의 관계 연구, 한국교원대학교 교육 대학원 석사학위논문.

박관성(1998). 담임교사효능감 척도의 타당화를 위한 일 연구, 이화여자대학교 교육대학원 석 사학위논문.

박병량(2001). 훈육: 학교 훈육의 이론과 실제, 서 울: 학지사.

박지원(1985). 사회적 지지 척도 개발을 위한 일 연구, 연세대학교 박사학위논문.

백희철(2004). 초등학교 교사의 지도성 유형과 아 동의 학교생활 만족도에 관한 연구, 전주교육 대학교 교육대학원 석사학위논문.

성병창 - 김세희(2003). 학급 훈육문제 발생 행동 의 특성과 대처 전략에 대한 이해, 초등교육연 구 16(2), 253-281.

송병숙(1998). 아동의 교사에 대한 지각이 자아개 념 및 학업성취에 미치는 영향, 이화여자대학 교 대학원 석사학위논문

송희숙(2002). 동아리 활동이 고등학생의 학교생 활만족도에 미치는 영향에 관한 연구, 인하대 학교 대학원 석사학위논문.

양은정(2007). 초등학교 고학년 학생이 지각한 교 사의 훈육유형에 따른 교사-학생 관계와 학교 적응의 차이, 계명대학교 교육대학원 석사학위 논문.

원진욱(2005). 초등학생이 지각한 교사유형과 학 교생활 만족도의 관계, 이화여자대학교 교육대 학원 석사학위논문.

원효헌·조명임(2008). 중학교 교사의 의사결정 참여수준과 조직효과성의 관계, 수산해양교육 연구 20(2), 286 296.

윤광순(2005). 교사 행동에 대한 아동의 지각과 학교생활 만족도의 관계, 순천대학교 교육대학 원 석사학위논문.

윤순홍(1988). 수업사태에서 교사 행동에 대한 아 동의 지각과 정의적 특성 간의 관계, 한국교원 대학교 교육대학원 석사학위논문.

이미숙(2001). 교사의 훈육유형과 아동의 친사회 
적 행동에 관한 연구, 부산대학교 교육대학원 석사학위논문.

이보미(1999). 부모의 양육방식과 교사의 훈육방 식에 대한 학생의 지각과 학습태도 및 문제행 동과의 관계, 전북대학교 석사학위논문.

이선심(2004). 초등학교 아동이 지각한 교사유형 과 자아존중감 및 학습태도 와의 관계, 한국교 원대학교 교육대학원 석사학위논문.

이선영 (2004). 초등학교 교사의 훈육유형과 아동 의 자기통제 관계 분석, 한국교원대학교 교육 대학원 석사학위논문.

이시연 (2007). 상업계 고등학교 학생들의 학교생 활만족에 관한 연구, 경기대학교 교육대학원 석사학위논문.

이은주(2003). 초등학생이 지각한 교사행동과 학 교생활만족도와의 관계, 경희대학교 교육대학 원 석사학위논문.

이재웅(2006). 고등학생의 학교생활만족도에 관한 연구, 관동대학교 교육대학원 석사학위논문.

이현주(2002). 실업계 고등학교 학생들의 학교생 활만족도 비교연구, 경희 대학교 교육대학원 석사학위논문.

임명숙(1997). 초등학생의 학교생활 만족도에 관 한 연구, 한남대학교 교육대학원 석사학위논문. 장신국(2002). 대안학교 고교생과 일반계 고교생 의 학교생활 만족도 비교연구, 전북대학교 교 육대학원 석사학위논문.

장한기 - 박종운 - 이상봉(2006). 컴퓨터 특성화고 등학교애 대한 교사와 학생의 인식, 수산해양 교육연구 18(2), 183 193.

장한기 - 장홍석 (2001). 중등교사가 인식하는 유 능한 교사의 자질, 수산해양교육연구 13(1), 37 62.

조병남(2009). 계 고등학교 학생들의 학교생활 만 족도에 관한 연구, 관동대학교 교육대학원 석 사학위논문.

조진용(2004). 인문 - 실업계 고등학교 학생들의 학교생활만족도 분석, 관동대학교 교육대학원 석사학위논문.

최경소(2003). 고등학교 학생들의 학교생활 만족 도에 관한 연구, 관동대학교 교육대학원 석사 학위논문

최상미(2003). 초등학생이 지각하는 교사문화와 학생의 학교생활만족에 관한 연구, 인천교육대 학교 교육대학원 석사학위논문.

최정희(2006). 중학생들의 학교생활 만족도 차이
분석, 전북대학교 교육대학원 석사학위논문.

한종혜(1996). 아동의 사회적 관계망에 따른 역량 지각 및 자아존중감, 경희대학교 대학원 박사 학위논문.

한주희(2000). 인간관계 집단상담이 자아존중감과 학교생활만족도에 미치는 영향, 아주대학교 교 육대학원 석사학위논문.

홍계옥(2003). 유아교사의 훈육행동과 관련변인에 대한 연구, 영유아교육연구 6, 59 74.

황영덕(2008). 농업계 고등학교 담임교사의 훈육 유형과 학교부적응 행동 수준의 관계, 서울대 학교 대학원 석사학위논문.

Akgun, S., \& Ciarrochi, J.(2003). Learned resourcefulness moderates the relationship between academic stress and academic performance, Educational Psychology 23, 277 294.

Allen, S., \& Hiebert, B.(1991). Stress and coping in adolescents, Canadian Journal of Counseling 5, 19 32.

Arnstein, R. L.,(1980). The student, the family, the universtiy, and transition to adulthood, Adolescent Psychology 8, 160 172.

Armsden, G. C., \& Greenberg, M. T.(1987). The inventory of parent and peer attachment: Individual difference and their relationship to psychological well-being in adolescence, Journal of Youth and Adolescence 16, 427 453.

Alderman, T.(2001). In good discipline, one size doesn't fit all. The Education Digest 66(8), 33 41.

Baldwin, B., Slaton, E., Head, M., \& Burns, J. (1990). Personality factors of elementary and secondary pre-service teachers, (ERIC Document Reproduction Service No. ED 326 522)

Battisrich, V., Schaps, E., Watson, M., \& Solomon, D.(1996). Prevention effects of the child development project: Early finding from an ongoing multisite demonstration trial, Journal of Adolescent Research 11, 12 35.

Bhushan, V.(1985). Relationship of teacher attitude to the environment of his/her class, (ERIC Document Reproduction Service No. ED 260 118)

Bloom, B. S.(1972). Innocence in education, The School Review 80(3), 333 352. 
Brophy, J. E., Rohkrkemper, M.(1982). The influence of problem ownership on teacher's perceptions of and strategies for coping with problem student, Journal of Ectucation Psychology 73(3), 295 311.

Burr, W. R.(1970). Satisfaction with various aspects of marriage over the life cycle: A random middle class samples, The Journal of Marriage and Families 32(1), 29 37.

Campbell, A.(1976). Identification and measurement of levels and standards of living, Journal of Home Economics 57(1), 4.

Canter, L.(1992). Assertive Discipline: Positive Behavior Management for Today's Classroom (2nd ed.). CA: Canter \& Associates.

Charles, C. M.(1996). Building classroom discipline (5th ed.), New York: Longman Publishers.

Charles, C. M.(2002). Building classroom discipline (7th ed.), New York: Longman Publishers.

Cobb, S. (1976). Social support as a moderator of life stress. psychosomatic Medicine, 38(5), 301 314.

Cohen, S., \& Hoberman, H.(1983). Positive events and social supports as buffers of life change stress, Journal of Applied Social Psychology 13, 99 125.

Curwin, R., \& Mendler, A.(1988). Discipline with dignity, Alexandria, V.A: Association for Supervision and Curriculum Development.

Dreikurs, R.(1968). Psychology in the classroom $A$ manual for teachers (2nd ed.), New York: Harper \& Row.

Driekurs, R.(1972). Coping with Children's Misbehaviour, New York: Hawthorne.

Dreikurs, R., Grunwald, B., \& Pepper, F.(1982). Maintaining sanity in the classroom New York: Harper \& Row.

Edwards, C. H.(2000). Classroom discipline and management (3rd ed), New York: John Wiley \& Sons, Inc.

Emmer, E. T., Evertson, C. M., Sanford, J. P., Clements, B. S., \& Worsham, M. E.(1989). Classroom management for Secondary Teachers (2nd ed.) Englewood Cliffs, NJ: Prentice-Hall.

Feldhusen, J. F.(1978). Behavior problems in secondary schools, Journal of Research and
Development in Education 11(4), 17 28.

Flanders, N.(1960). Teacher influence, pupil attitudes and achievement, Minneapolis: University of Minnesota.

Fraser, B. J., \& Walberg, H. J. (Eds.).(1991). Educational environments: Evaluation, antecedents, and consequences, Oxford: Pergamon.

George, L. K.(1979). The Impact of Personality and Social Status Factors upon Levels of Activity and Psychological Well-Being, Journal of Gerontology, 33(1), 6.

Ginott, H.(1971). Teacher and Child, New York: Macmillan.

Glasser, W.(1986). Control theory in the classroom, New York: Harper and Row.

Gottman, J., Declaire, J.(1997). The heart of parenting: raising an emotionally intelligent child New York: Simon and Schuster.

Harris, L. et al(1984). The New York state teather, The metropolitan life survey, ERIC Document Reproduction Service No. ED 255512.

House, J, S.(1982). Work sterss and social support, MA: Addison-Wesley Publishing Co.

Howes, C., Hamilton, C. E., \& Matheson, C. C. (1994). Children's play in child care settings, Albany State University of New York Press.

Kounin, J. S.(1970). Discipline and group management in classroom, N. Y.: Holt, Renehart and Winston.

Levin, J., \& Nolan, J. F.(1996). Principles of classroom management: a professional decision-making model (2nd ed.), Boston: Allyn and Bacon.

Lickona, T.(1991). Ecucating for character: how our schools can teach respect and responsibility, New York: Bantam.

McGuire, K. D., \& Weisz, J. R.(1982). Social Cognition and Behavior Correlates of Preadolescent Chumship, Journal of Child Development 53(4), 478 484.

Pianta, R. C., Steinberg, M. S., \& Rollings, K. B.(1995). The first two years of school: teacher-child relationships and deflections in children's classroom adjustment, Development and Psychopathology 7(2), 295 312.

Purvis, J. J.(1994). Teacher attitude toward discipline, the university of southern Mississippi. 
Shrigley, R. L.(1979). Strategies in classroom management, The National Association of Secondary School Principals Bulletin 63(8), 1 15.

Tomal, D. R.(1998). A five-styles teacher discipline model. Paper presented at the annual Meeting of Mid-Western Educational Research Association, Chicago, IL, October, 14-17, (ERIC Dodument Reproduction Service No. ED 425 158)

Tomal, D. R.(2001). A comparison of elementary and high school teacher discipline styles, American Secondary Education, 30(1), 38 45.

Tulley, M., \& Chiu, L. H.(1995). Student teachers and classroom discipline, Journal of Educational Research 88(3), 164 172.

Vaux, A.(1988). Social support: Theory, research, and intervention, New York: Preager.
Wolfgang, C. H., \& Glickman, C. D.(1986). Solving discipline problems: strategies for classroom teachers (2nd ed.), New York: Allyn and Bacon.

Wolfgang, C. H.(2001). Solving discipline and classroom management problems: methods and models for today's teachers (5th ed.), New York: John Wiley \& Sons.

교육통계서비스 홈페이지. http:// cesi kedi. re.kr

- 논문접수일 : 2012년 10월 25일

- 심사완료일 : 1차 - 2012년 11월 10일

2차 - 2012년 11월 18일

- 게재확정일 : 2012년 11월 21일 